\title{
Frequency and spontaneous cytotoxicity of natural killer cells in healthy children: preliminary results
}

\author{
KATARZYNA POPKO ${ }^{\prime}$, IWONA MALINOWSKA ${ }^{2}$, MARTA RYCHTA ${ }^{1}$, IWONA OSINSSKA \\ ELŻBIETA GÓRSKA ${ }^{l}$, ANNA KUCHARSKA ${ }^{4}$, URSZULA DEMKOW' \\ ${ }^{1}$ Department of Laboratory Diagnostics and Clinical Immunology of Developmental Age, Medical University of Warsaw, Poland \\ ${ }^{2}$ Department of Pediatrics, Hematology and Oncology, Medical University of Warsaw, Poland \\ ${ }^{3}$ PhD Student, First Faculty of Medicine (Department of Pathology), Medical University of Warsaw, Poland \\ ${ }^{4}$ Department of Pediatrics and Endocrinology, Medical University of Warsaw, Poland
}

\begin{abstract}
Natural killer (NK) cells account for up to $15 \%$ of all peripheral blood lymphocytes and are characterized phenotypically by the presence of CD56/CD16 antigens and the lack of CD3 antigen. Natural killer cells exert cytotoxic functions against a variety of target cells including tumor cells, virus-infected cells and normal hematopoietic cells expressing allogeneic major histocompatibility complex (MHC) antigens. Human NK cells can be divided into five subsets with different biological functions: CD56right CD16-CD56 bright $C D 16^{\text {dim }}, C D 56^{\text {dim }} C D 16^{-}, C D 56^{\text {dim }}$ CD16 $^{\text {bright }}$, and CD56- CD16 bright.

The aim of the study was to analyze the frequency and activity of $N K$ cells from the peripheral blood of healthy children aged 6-17 years $(n=18)$.

The tests were performed with the use of flow cytometer EPICS XL (Beckman Coulter).

We have shown that the cytotoxic activity of $N K$ cells differed significantly from one another. The study proves that the overall cytotoxic activity of NK cells depends on the number of peripheral blood cells $(p=0.01)$ in a healthy children population.
\end{abstract}

Key words: NK cells, cytotoxicity, innate immunity, children.

(Centr Eur J Immunol 2013; 38 (4): 562-568)

\section{Introduction}

Normal function of the immune system depends on the proper number and activity of immunocompetent cells of different lineages. Natural killer (NK) cells are a subset of lymphocytes that contribute to innate immunity and can be defined as CD16+/CD56+/CD3- cells.

Natural killer cells exert spontaneous cell-mediated cytotoxicity against tumor cells, virus infected cells and other host cells with a decreased expression of allogeneic MHC (major histocompatibility complex) antigens. Natural killer cells account for up to $15 \%$ of circulating lymphocytes [1-6].

In humans five different subsets of NK cells may be distinguished on the basis of cell surface density of CD56 and expression of CD16: CD56 $6^{\text {bright }} \mathrm{CD} 16^{-}, \mathrm{CD} 56^{\text {bright }} \mathrm{CD}$ $16^{\mathrm{dim}}, \mathrm{CD} 56^{\mathrm{dim}} \mathrm{CD} 16^{-}, \mathrm{CD}^{\mathrm{dim}} \mathrm{CD} 16^{\text {bright }}$, and CD56- CD$16^{\text {bright }}$. There is some evidence that CD56 $6^{\mathrm{dim}}$ cells show a higher cytotoxic activity in comparison with CD56 $6^{\text {bright }}$ cells [7, 8]. A high expression of CD16 molecule on NK cell surface enables more effective antibody-dependent cytotoxicity. On the other hand, CD56 $6^{\text {bright }}$ cells are most effective in cytokine production [interferon $\gamma$ (IFN- $\gamma$ ), tumor necrosis factor $\alpha$ (TNF- $\alpha$ ), GM-CSF, interleukin (IL) 10, IL-13 [9].

Natural killer cells induce cytolysis through cytolytic granule-mediated apoptosis or antibody-dependent cell-mediated cytotoxicity (ADCC). Direct cytotoxic effect depends on the balance between stimulatory and inhibitory signals. Three major receptor families have been described on the surface of NK cell membrane: killer cell Ig-like receptors (KIR) which recognize HLA-A, -B and C; lectin-like receptors including CD94 and NKG2A/B receptors recognizing HLA-E, and natural cytotoxicity receptors including NKp30, NKp44 and NKP46 with unknown ligands [2, 10-17]. NKp30 and NKp46 receptors are constitutively expressed on NK cells, whereas NKp44 appears only after

Correspondence: Katarzyna Popko, Department of Laboratory Diagnostics and Clinical Immunology of Developmental Age, Medical University of Warsaw, Marszałkowska 24, 00-576 Warsaw, Poland, e-mail: aksiak@interia.pl 
stimulation [18]. CD16 molecule plays an essential role in biology and function of NK cells. This is a low affinity FcyRIII receptor which binds to antibody-opsonized target cells and signals through associated subunits containing an immunoreceptor tyrosine-based activation motif (ITAM) to direct antibody-dependent cell-mediated cytotoxicity (ADCC). Most of NK cells with a high CD56 expression do not express CD16 antigen or its expression is low, whereas over $95 \%$ of NK cells with a low CD56 expression are CD16 positive [7].

Cytolytic abilities of NK cells depend on the content and activity of intracellular granulosomes. A cortex of granulosome contains proteolytic enzyme - perforin, whereas a core contains granzymes. In the first stage, membrane of target cell is permeabilized by perforin, then proteolytic enzymes - granzymes - activate intracellular targets cell caspases leading to apoptosis. Several cytokines including: IL-2, IFN- $\alpha$, IFN- $\beta$, IL-12, IL-18, IL-21, IL-15, as well as bacterial and viral proteins, can enhance spontaneous cytotoxicity of NK cells [19-22].

Immunosuppression and disorders affecting the function and/or number of NK cells may lead to instability of the immune system and uncontrolled proliferation of pathologically changed cells. In consequence, this may lead to development of tumors and/or autoimmunization $[23,24]$. It is also suggested that some kinds of cancers may induce anergy in NK cells through secretion of inhibitory factors or elevated NFKB activity $[25,26]$.

One of the most severe disorders characterized by NK cell cytotoxic function impairment is hemophagocytic lymphohistiocytosis (HLH). It may lead to uncontrolled hyper activation of macrophages which phagocyte erythrocytes, leukocytes, platelets and their precursors within bone marrow, liver and lymph nodes. As a consequence, patients suffer from fever, advanced pancytopenia and hepatosplenomegaly. Hemophagocytic lymphohistiocytosis is a life-threatening disease. The major aim of HLH treatment is to suppress severe hyper inflammation by a combined action of dexamethasone, cyclosporine and etoposide. Steroids are cytotoxic for lymphocytes and inhibit secretion of cytokines. Cyclosporine prevents T lymphocytes proliferation. Etoposide is highly effective in treatment of monocyte and histiocytic diseases. Patients with a low risk (without genetic background of HLH) may be treated only with steroids and cyclosporine. In the most severe congenital cases, only stem cell transplantation and replacement of defective immune cells by normal functioning cells is a successful treatment [27].

Currently, methods evaluating the phenotype, cytokine production and proliferation capacity of NK cells are well described, but cytotoxic activity is still rarely investigated. Moreover, the range of cytotoxic activity in normal subjects of different age and sex is not completely known. To date the reference cytotoxicity test based on radioactive chromium as an indicator of target cells was the only diag- nostic method of spontaneous cytotoxicity. Nowadays, the technique brings several technical problems for numerous laboratories. The use of radioactive chemical elements requires specialized, highly qualified and certified isotopic laboratory. The best alternative is a new flow cytometric method applied and described by many authors [28-32]. In this method, staining with radioactive chromium is replaced with various fluorescence stains. Flow cytometry gives a broad operating range with diverse modifications and applications [33]. However, the flow cytometry method is still rarely used in routine diagnostic procedures and demands additional operation research.

The aim of this study was to find a correlation between spontaneous cytotoxic activity, measured by the flow cytometric method, and the number of circulating NK cells in a group of healthy children.

\section{Material and methods}

Eighteen healthy children and adolescents aged from 6 to 17 years (10 girls and 8 boys) were enrolled to the study. Parents of the investigated children gave informed consent during the enrollment visit, having been fully informed of the nature, risk and potential benefits of the study. For elder children ( $>15$ years) their permission was also obtained. The Ethical Committee of the Medical University of Warsaw approved the study protocol. Each individual was assessed clinically by a pediatrician or by a research physician for eligibility to take part in the study. Children were free from any allergic diseases, immune and hematological disorders. Healthy children referred to the Children Hospital of Medical University of Warsaw were qualified for routine health screen or minor surgical procedures. Blood collection was performed at least three months after the last episode of infection, vaccination and any medication, and at least 3 months after the last episode of viral diseases such as mononucleosis or chickenpox. For all analyses, $3.2 \mathrm{ml}$ of venous blood was drawn to the tubes containing heparin.

\section{Flow cytometric analysis of the phenotype and frequency of natural killer cells}

Leukocyte concentration in the whole blood sample was adjusted to $4 \times 10^{6} / \mathrm{ml}$ with $\mathrm{NaCl}$. Next, $100 \mu \mathrm{l}$ of blood was incubated with $10 \mu \mathrm{l}$ of ready-to-use monoclonal antibodies solutions: anti-CD3 FITC, anti-CD16CD56 PE, anti-CD45PC5 (Becton Dickinson) according to the manufacturer's protocol, protected from light, $20 \mathrm{~min}$ at room temperature. After staining, the erythrocytes were lysed with $500 \mu$ l of OptiLyse C reagent (Beckman Coulter). The samples were analyzed by flow cytometry using appropriate isotype controls. Lymphocytes were recognized and gated according to the side scatter (lymphocytes present side scatter lower than monocytes and 
polymorphonuclears) and CD45 expression (lymphocytes present the highest expression of CD45 antigen among whole blood leukocytes). Nonviable cells and debris were removed from analysis based on very low forward scatter and side scatter and lack of CD45 antigen expression. Acquisition was run to the total number of 10000 events in lymphocyte gate. Flow cytometric analyses were performed using Cytomix FC 500 Beckman Coulter. Instrument setup and calibration was performed with the use of Flow-Check Pro Fluarospheres (Beckman Coulter) according to manufacturer's protocol.

\section{Flow cytometric cytotoxicity test}

Peripheral blood mononuclear cells (PBMC) from $3 \mu \mathrm{l}$ of anticoagulated, heparinized blood were separated by density gradient centrifugation (Histopaque 1077, Sigma-Aldrich). After separation, the cells were suspended in RPMI media at a final concentration $4 \times 10^{6} / \mu 1$.

Target cells were harvested from the culture, washed and suspended in RPMI media at the final concentration of $1 \times 10^{6} / \mathrm{ml}$. Natural killer-mediated cytotoxicity was analyzed as described previously [30]. Target cells (K562) were labeled with fluorescent dye $\mathrm{DiO}_{18}$ (3.3-dioctadecyloxacarbocyanine perchlorate, Sigma-Aldrich). $10 \mu \mathrm{l}$ of the stock solution ( $3 \mathrm{mM}$ in DMSO) was added to $1 \times 10^{6}$ of K562 cells suspended in $1 \mathrm{ml}$ of RPMI media and incubated at $37^{\circ} \mathrm{C}, 5 \% \mathrm{CO}_{2}$ for $30 \mathrm{~min}$. After incubation, the cells were washed 3 times in PBS and once in RPMI (to wash out the excess of unbound DIO dye) and suspended in RPMI media to the final concentration of $1 \times 10^{6} / \mathrm{ml}$.
Separated PBMC were cultured with target K562 cells in 3 sterile tubes: tube 1 - effector $(\mathrm{E})$ to target $(\mathrm{T})$ cells ratio (E : T) $13: 1$, tube 2 - control with effector PBMC without target K562 cells, tube 3 - control with target K562 without PBMC. The culture was incubated for $4 \mathrm{~h}$ in humidified at $37^{\circ} \mathrm{C}, 5 \% \mathrm{CO}_{2}$ atmosphere. After $4 \mathrm{~h}$ the tubes were stained with $5 \mu \mathrm{l}$ of propidium iodide (PI) $(50 \mu \mathrm{g} / \mathrm{ml}$ stock) and left for another 30 min incubation. Afterwards, the samples were acquired to flow cytometer to the final number of 5000 events presenting $\mathrm{DiO}$ fluorescence.

Propidium iodide as well as $\mathrm{DiO}_{18}$ are excited with an argon-ion laser tuned to $100 \mathrm{~mW}$ at $488 \mathrm{~nm}$. Red fluorescence from propidium iodide-stained cells was deflected by $610 \mathrm{~nm}$ short-pass dichroic, passed through a 630 band-pass filter and detected on photomultiplier FL3. Green fluorescence from $\mathrm{DiO}_{18}$ - stained cells was collected through a $560 \mathrm{~nm}$ short-pass dichroic, passed through a $530 \mathrm{~nm}$ band-pass filter and detected on photomultiplier FL1. A two-parameter cytogram, log (FL1) versus log (FL3) was plotted to discriminate the different cell types in the experiment. Live target (K562) cells showed only $\mathrm{DiO}_{18}$ fluorescence (D4), dead target cells showed both $\mathrm{DiO}_{18}$ and PI fluorescence (D2) (Fig. 1B). The percentage of dead target cells was calculated according to the following formula: dead cells $\times 100 \%$ /total number of target cells. A specific lysis index (\% of cytotoxic activity) was calculated as follows: [the percentage of dead target cells (including effector cells)] - [dead target cells (without effector cells)] (Fig. 1A).
A

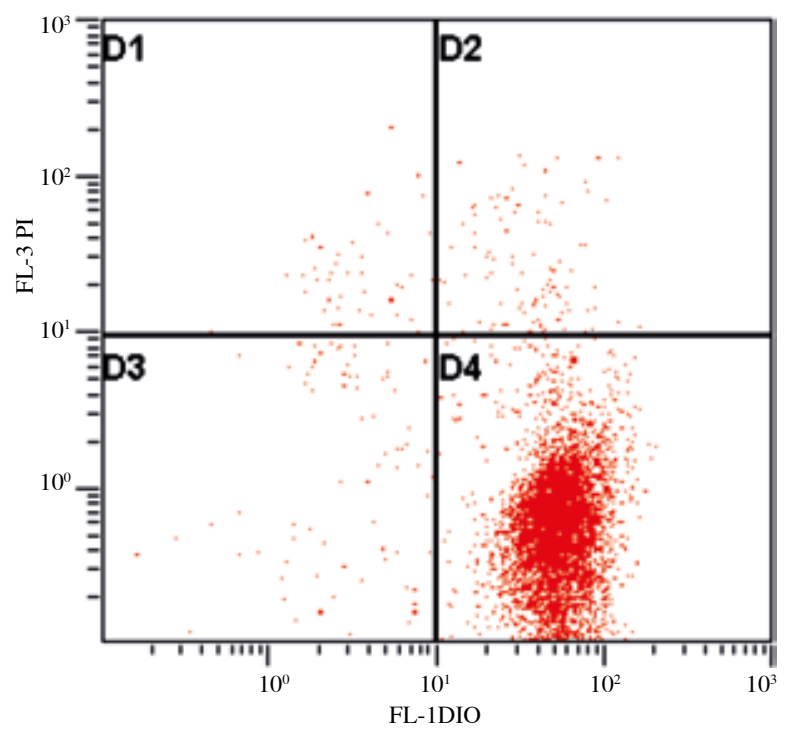

$\mathrm{B}$

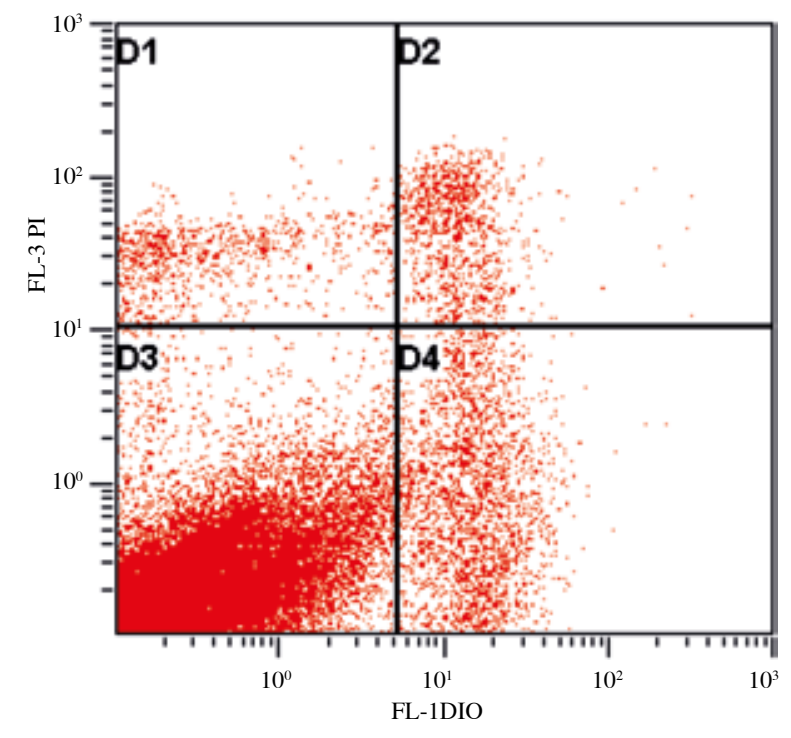

Fig. 1. Cytotoxicity test using flow cytometry (A) target cells without effector cells, (B) target cells with effector cells 
Table 1. Results of cytotoxicity test and the percentage of NK cells

\begin{tabular}{|c|c|c|c|c|}
\hline No. & Sex & Age & $\%$ NK & $\begin{array}{c}\% \\
\text { Cytotoxicity }\end{array}$ \\
\hline 1 & M & 16 & 17.7 & 22.5 \\
\hline 2 & $\mathrm{~F}$ & 10 & 6.5 & 4.0 \\
\hline 3 & $\mathrm{~F}$ & 11 & 18.5 & 14.3 \\
\hline 4 & $\mathrm{~F}$ & 12 & 12.0 & 10.6 \\
\hline 5 & M & 11 & 10.8 & 11.3 \\
\hline 6 & M & 17 & 9.8 & 11.4 \\
\hline 7 & M & 10 & 9.3 & 4.8 \\
\hline 8 & $\mathrm{~F}$ & 12 & 9.4 & 19.8 \\
\hline 9 & M & 13 & 6.3 & 5.1 \\
\hline 10 & M & 12 & 7.2 & 14.5 \\
\hline 11 & M & 10 & 1.2 & 1.2 \\
\hline 12 & $\mathrm{~F}$ & 11 & 7.0 & 13.2 \\
\hline 13 & M & 13 & 13.0 & 13.2 \\
\hline 14 & $\mathrm{~F}$ & 10 & 12.6 & 15.8 \\
\hline 15 & $\mathrm{~F}$ & 11 & 10.7 & 21.6 \\
\hline 16 & $\mathrm{~F}$ & 10 & 8.11 & 4.5 \\
\hline 17 & $\mathrm{~F}$ & 6 & 5 & 10.8 \\
\hline 18 & $\mathrm{~F}$ & 6 & 11.8 & 9.7 \\
\hline median & & & 10.1 & 11.3 \\
\hline 25 percentile & & & 7.0 & 5.1 \\
\hline 75 percentile & & & 12.0 & 15.8 \\
\hline
\end{tabular}

Statistical calculations were performed using Statistica 10 software. Shapiro-Wilk test was used to analyze distribution of the studied variables. Differences between two groups were assessed using the Mann-Whitney $U$ test. Correlation strength between the number of NK cells and cytotoxicity was assessed using Spearman correlation test. Statistical significance was considered at $p<0.05$.

This work was approved by the Ethical Committee of the Medical University of Warsaw. The study was conducted according to the Helsinki Declaration.

\section{Results}

The percentage of NK cells in a population of lymphocytes was assessed by flow cytometry using anti CD16+56, and CD3 monoclonal antibodies. Only cells expressing CD56 and/or CD16 antigens without the expression of CD3 were considered NK cells.

The detailed results of cytotoxicity tests and the percentage of NK cells in whole blood are shown in Table 1.

Although the mean value of spontaneous NK activity in the group of girls was higher than in the group of boys, statistical significance was not achieved $(p=0.7)$ (Fig. 2). No difference was found in the percentage of circulating NK cells between girls and boys ( $p=0.8$ ) (Fig. 3).

There was a high correlation between spontaneous NK cell cytotoxicity and the frequency of NK cells in the blood stream $(p=0.01 ; r=0.55)$. A positive correlation was observed in the whole analyzed population (Fig. 4), as well as in the groups of boys and girls when analyzed separately.

\section{Discussion}

The phenomenon of natural cytotoxicity was discovered at the beginning of the 1970s as the ability of a certain population of lymphocytes to exert a cytotoxic reaction against tumor cells. In the group of patients suffering from malignant diseases, the activity of lymphocytes against autologous and/or allogeneic neoplastic cells was lower when compared to the activity of lymphocytes isolated from healthy subjects. The function of NK cells is currently understood to be controlled by a dynamic signal balance between activating and inhibiting receptors engaged upon interaction with ligands presented on the surface of the target cell [7, 9, 34].

The range of NK cells number in the whole blood of healthy subjects as well as spontaneous cytotoxic activity may vary. It was found that individual NK cells activity depends on the genetic background and environmental factors $[18,35,36]$. On the basis of repeated analyses of the same individuals, the activity of NK cells turned out to be quite stable. Probably it is settled during the first year of life and is only slightly modified by environmental factors [37]. It was also confirmed that relative and absolute numbers of NK cells remain almost invariable during early childhood. In further life, the percentage of circulating NK cells seems to increase, but absolute counts remain almost invariable [38]. All children enrolled to our study (except one) had NK cell numbers within age-related normal values.

Certain differences in NK cell number and their activity in blood were observed between men and women. At the beginning of the 1980s, Penschow and Mackay had investigated cytotoxic activity of NK cells in a group of healthy subjects ( 26 women and $17 \mathrm{men}$ ). They found that spontaneous NK activity was significantly higher in men than in women [39]. Yovel with collaborators had analyzed the correlation between gender, menstrual cycle, or 


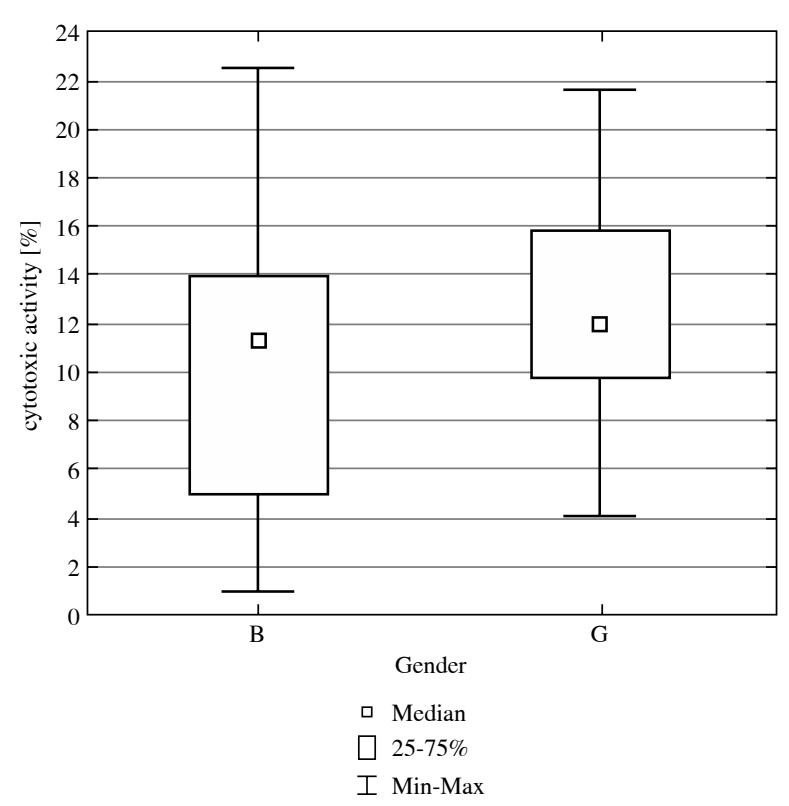

Fig. 2. The difference in the value of spontaneous cytotoxicity between girls (G) and boys (B) (Mann-Whitney $U$ test $p=0.7$ )

oral contraceptives and NK cells number and their cytotoxic activity. They revealed that NK activity was higher in men than in women with regular menstrual cycles. The lowest values were found in a group of women taking oral contraceptives [40].

In our study, the number of NK cells and their cytotoxic activity were higher in the group of girls, but most girls were in the pre-pubertal age.

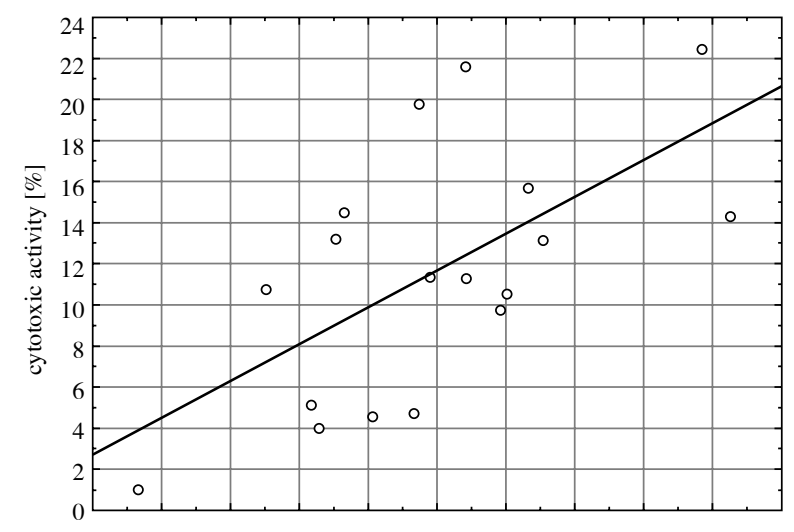

Fig. 4. The Spearman correlation between the number of NK cells and spontaneous cytotoxicity $(p=0.01 ; r=0.55)$

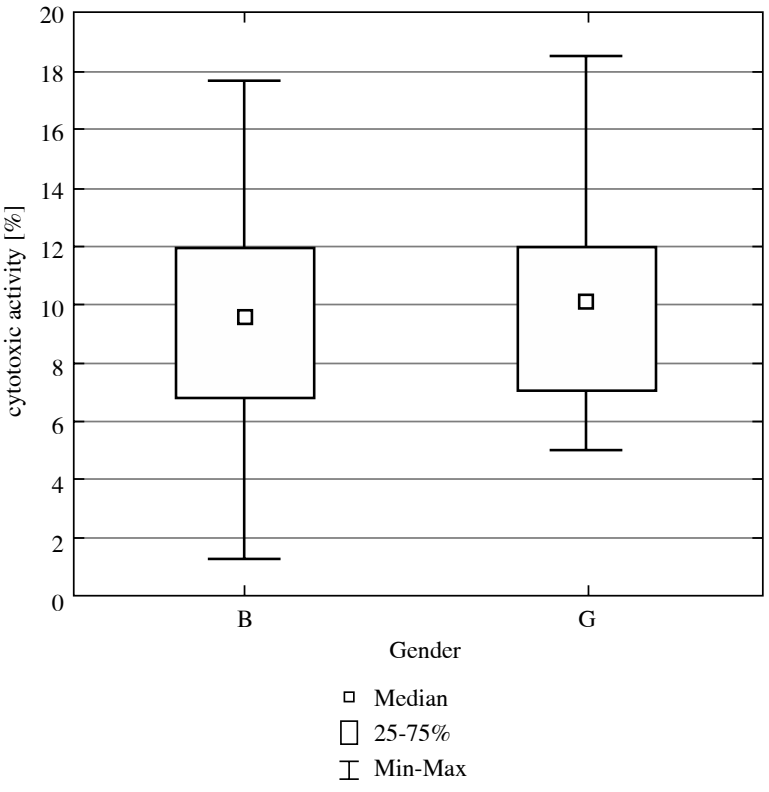

Fig. 3. The difference in the number of circulating NK cells between girls (G) and boys (B) (Mann-Whitney $U$ test $p=0.8$ ).

Gender-related differences in the number and activity of NK cells highlight the link between gonadotropic and sex hormones and NK cell development. The concentration of luteinizing hormone ( $\mathrm{LH}$ ), follicle-stimulating hormone (FSH), estradiol and progesterone increases in girls between 8 and 10 years of age. Approximately at the age of 16 the concentration of all sex hormones reaches the level observed in mature women [40]. Seaman et al. had demonstrated in an animal study that prolonged exposure to estrogen significantly decreased cytotoxic activity [41]. Other authors had observed the correlation between NK activity and gonadal hormones level in the course of the menstrual cycle. Sulke et al. had found a significant drop of NK cytotoxic activity at the moment of ovulation. Natural killer cells activity was higher in the follicular phase than in the luteal phase [42].

Physical activity also has an important influence on NK cells number and efficiency. This influence depends on the intensity of the exercise. It was revealed that a serious and rapid increase in NK activity after physical effort was connected with an increased number of circulating CD56+ cells. Moreover, it was observed that moderate, long-lasting effort may cause a persistent increase in resting activity of NK cells [37, 43, 44]. Psychological stress and regular blood donation are also considered as factors decreasing cytotoxic activity of NK cells [45, 46].

The presence of several disturbances of NK cells activity may lead to the development of pathological conditions, such as cancer, viral infections or autoimmune diseases. 
It is well known that patients suffering from autoimmune disorders are highly predisposed to development of severe complications, like macrophage activation syndrome (MAS) and hemophagocytic syndrome (HLH). Macrophage activation syndrome is caused by hyperactivation of immune response as a consequence of an impaired NK cells function. Patients with such autoimmune disorders as systemic juvenile idiopathic arthritis (SJIA) and type 1 diabetes are predisposed to this syndrome. Hemophagocytic syndromes were also described as a complication of several other autoimmune disorders, e.g. systemic lupus erythematosus (SLE), juvenile dermatomyositis or Kawasaki disease [47-50]. Unfortunately, numerous cases of MAS and HLH remain undiagnosed and appropriate treatment is not applied. Lack of the right diagnosis may result in severe complications including patients' death [51]. It is therefore essential to recognize NK cell defects and predict or even prevent the progression of the underlying disease.

In our study, we found a positive correlation between the number of circulating NK cells and the activity of spontaneous cytotoxicity. Such correlation might not always be true for NK cells. The presence of disturbances in NK cell function may affect this correlation. So that it might be an oversimplification to assume normal NK cell function when the cell count falls within normal range.

The results of the presented study indicate that the level of individual cytotoxicity in children without defects in NK cells function or severe immune diseases depends on the frequency of NK cells. However, the influence of the other factors like age, gender and state of health should also be considered.

The authors declare no conflict of interest.

\section{References}

1. Caligiuri MA (2008): Human natural killer cells. Blood 112: 461-469.

2. Farag SS, Caligiuri MA (2006): Human natural killer cell development and biology. Blood Rev 20: 123-137.

3. Lanier LL (2006): Natural killer cell: roundup. Immunol Rev 214: 5-8.

4. Robertson MJ, Ritz J (1990): Biology and clinical relevance of human natural killer cells. Blood 76: 2421-2438.

5. Spits H, Lanier LL, Phillips JH (1995): Development of human $\mathrm{T}$ and natural killer cells. Blood 85: 2654-2670.

6. Trinchieri G (1989): Biology of natural killer cells. Adv Immunol 47: 187-376.

7. Cooper MA, Fehniger TA, Caligiuri MA (2001): The biology of human natural killer-cell subset. Trends Immunol 22: 633-640.

8. Cooper MA, Fehniger TA, Turner SC, et al. (2001): Human natural killer cells: a unique innate immunoregulatory role for the C56(bright) sunset. Blood 97: 3146-3151.
9. Wilk E, Kalippke K, Buyny S, et al. (2008): New aspects of NK cell subset identification and inference of NK cell' regulatory capacity by assessing functional and genomic profiles. Immunobiology 213: 271-283.

10. Biedroń M, Mazur G, Wróbel T, et al. (2003): Receptory komórek NK. Adv Clin Exp Med 12: 529-535.

11. Bryceson YT, March ME, Ljunggren H-G, et al. (2006): Synergy among receptors on resting NK cells for the activation of natural cytotoxicity and cytokine secretion. Blood 107: 159-166.

12. Colonna M, Navarro F, Bellón T, et al. (1997): A common inhibitory receptor for major histocompatibility complex class I molecules on human lymphoid and myelomonocytic cells. J Exp Med 186: 1809-1818.

13. Farag SS, Fehniger TA, Ruggeri L, et al. (2002): Natural killer cell receptors: New biology and insights into the graft-versus-leukemia effect. Blood 100: 1935-1947.

14. Ferlazzo G, Tsang ML, Moretta L, et al. (2002) Human dendritic cells activate resting natural killer (NK) cells and are recognized via the NKp30 receptor by activated NK cells. J Exp Med 195: 343-354.

15. Held WD, Coudert JD, Zimmer J (2003): The NK cell receptor repertoir: formation, adaptation and exploitation. Curr Opin Immunol 15: 233-237.

16. Kopeć-Szlęzak J, Podstawka U (2007): Biologia komórek NK. Onkol Pol 10: 115-119.

17. Voss SD (1998): Participation of the CD94 receptor complex in costimulation of human natural killer cells. J Immunol 160: 1618-1626.

18. Moretta A, Bottino C, Vitale M, et al. (2001): Activating receptors and coreceptors involved in human natural killer cell-mediated cytolysis. Annu Rev Immunol 19: 197-223.

19. Biron CA (1997): Activation and function of natural killer cell responses during viral infections. Curr Opin Immunol 9: 24-34.

20. Biron CA, Nguyen KB, Pien GC, et al. (1999): Natural killer cells in antiviral defense: function and regulation by innate cytokines. Annu Rev Immunol 17: 189-220.

21. Smyth MJ, Cretney E, Kelly JM, et al. (2005): Activation of NK cell cytotoxicity. Mol Immun 42: 501-510.

22. Voskobojnik I, Smyth M, Trapani J (2006): Perforin-mediated terget-cell Heath and immune homeostasis. Nat Rev Immunol 6: 940-952.

23. Schleinitz N, Vel F, Harle JR, et al. (2010): Natural killer cells in human autoimmune diseases. Immunology 131: 451-458.

24. Zamai L, Pouti C, Mirandola P, et al. (2007): NK cells and cancer. J Immunol 178: 4011-4016.

25. Rayet B, Gelinas C (1999): Aberrant rel/nfkb genes and activity in human cancer. Oncogene 18: 6938-6947.

26. Jewett A, Tseng H-C (2011): Tumor induced inactivation of natural killer cell cytotoxic function; implication in growth, expansion and differentiation of cancer stem cells. J Cancer 2: 443-457.

27. Bhattacharyya M, Ghosh MK (2008): Hemophagocytic lymphohistiocytosis - recent concept. JAPI 56: 453-457.

28. Brenan M, Parish CR (1988): Automated fluorometric assay for T cell cytotoxicity. J Immunol Methods 112: 121-123.

29. Kim GG, Donnenberg WS, Donnenberg AD, et al. (2007): A novel multiparametric flow cytometry-based cytotoxicity assay simultaneously immunophenotypes effector cells: Comparisons to a $4 \mathrm{~h}{ }^{51} \mathrm{Cr}$-release assay. J Immunol Methods 325: 51-66. 
30. Mattis AE, Bernhardt, Lipp G, Forster MR (1997): Analyzing cytotoxic T lymphocyte activity: a simple and reliable flow cytometry-based assay. J Immunol Methods 204: 135142.

31. Papadopoulos NG, Dedoussis GV, Spanakos G, et al. (1994): An improved fluorescence assay for the determination for lymphocyte mediated cytotoxicity using flow cytometry. J Immunol Methods 177: 101-111.

32. Perfetto SP, Chattopadhyay PK, Lamoreaux L, et al. (2006): Amine reactive dyes: An effective tool to discriminate live and dead cells in polychromatic flow cytometry. J Immunol Methods 313: 199-208.

33. Popko K, Malinowska I, Gorska E, et al. (2013): Flow cytometry in detection of abnormalities of natural killer cell. Adv Exp Med Biol 756: 303-311.

34. Stasiak-Barmuta A, Alifier M, Rapiejko P, et al. (2009): Komórki NK - rola i udział w zdrowiu i chorobie. Alergoprofil 5: 5-11.

35. Sansoni P, Cossarizza A, Brianti V, et al. (1993): Lymphocyte subset and natural killer cell activity in healthy old people and centenarians. Blood 82: 2767-2773.

36. Shakhar K, Valdimarsdottir HB, Gueverra JS, et al. (2007): Sleep, fatigue, and NK cell activity in healthy volunteers: Significant relationship revealed by within subject analyses. Brain Behavior and Immunity 21: 180-184.

37. Tseng RJ, Padgett DA, Dhabhar FS, et al. (2005): Stress-induced modulation of NK activity during influenza viral infection: role of glucocorticoids and opioids. Brain Behav Immun 19: 153-164.

38. Piątosa B, Wolska-Kuśnierz B, Siewiera K, et al. (2010): Distribution of leukocyte and lymphocyte subsets in peripheral blood. Age related normal values for preliminary evaluation of the immune status in Polish children. Centr Eur J Immunol 35: 168-175.

39. Penschow J, Mackay IR (1980): NK and K cell activity of human blood: differences according to sex, age and disease. Ann Rheum Dis 39: 82-86.

40. Yovel G, Shakhar K, Ben-Eliyahu S (2001): The effects of sex, menstrual cycle, and oral contraceptives on the number and activity of natural killer cells. Gynecologic Oncology 81: 254-262.

41. Seaman WE (1978): Beta-estradiol reduces natural killer cells in mice. J Immunol 121: 2193-2198.

42. Sulke AN (1985): Variation in natural killer activity in peripheral blood during the menstrual cycle. Br Med J 290: 884-886.

43. Pedersen BK, Tvede N, Hansen FR, et al. (1988): Modulation of natural killer cell activity in peripheral blood by physical exercise. Scand J Immunol 27: 673-678.

44. Suzui M, Kawai T, Kimura H, et al. (2004): Natural killer cell lytic activity and CD56 $6^{\text {dim }}$ and CD56 $6^{\text {bright }}$ cell distributions during and after intensive training. J Appl Physiol 96: 2167-2173.

45. Marquet RL, Hoynck van Papendrecht MA, Busch OR, et al. (1993): Blood donation leads to a decrease in natural killer cell activity: a study in normal blood donors and cancer patients. Transfusion 33: 368-373.

46. Heiss MM, Fasol-Merten K, Allgayer H, et al. (1997): Influence of autologous blood transfusion on natural killer and lymphokine-activated killer cell activities in cancer burgery. Vox Sang 73: 237-245.

47. Carvalheiras G, Anjo D, Mendonca T, et al. (2010): Hemophagocytic syndrome as one of the main primary man- ifestations in acute SLE - case report and literature review. Lupus 19: 756-761.

48. Davi S, Consolaro A, Guseinova D, et al. (2011): An international consensus survey of diagnostic criteria for macrophage activation syndrome in systemic juvenile idiopathic arthritis. J Rheumatol 38: 764-768.

49. Fukaya S, Yasuda S, Hashimoto T, et al. (2008): Clinical features of haemophagocytis syndrome in patients with systemic autoimmune diseases: analysis of 30 cases. Rheumatol 47: 1686-1691.

50. Hendricks M, Pillay S, Davidson A, et al. (2010): Kawasaki disease preceding haemophagocytic lymphohistiocytosis: challenges for developing world practitioners. Pediatr Blood Cancer 54: 1023-1025.

51. Jędrzejczak WW (2008): Limfohistiocytoza hemofagocytarna - rzadko rozpoznawany uleczalny stan bezpośredniego zagrożenia życia występujący również u dorosłych. Acta Hematol Pol 39: 515-526. 